\title{
The effect of LED lighting on photosynthetic parameters and weight of lamb's lettuce (Valerianella locusta)
}

\author{
Renata Wojciechowska ${ }^{1 *}$, Anna Kolton ${ }^{1}$, Olga Dlugosz-Grochowska ${ }^{1}$, \\ Marek Żupnik², Wojciech Grzesiak ${ }^{3}$
}

${ }^{1}$ Department of Botany and Plant Physiology

University of Agriculture in Krakow

29 Listopada 54, 31-425 Krakow, Poland

${ }^{2}$ PXM Firm

Przemysłowa 12, 30-701 Krakow, Poland

${ }^{3}$ Institute of Electron Technology

Lotników 32/46, 02-668 Warsaw, Poland

\begin{abstract}
The experiment was carried out in the winter and autumn of 2011 using lamb's lettuce (Valerianella locusta Laterr. Em Betce) as a test plant under greenhouse growing conditions. The aim of the study was to evaluate the effect of a prolonged day with modern SSL LED (Solid State Lighting Light Emitting Diodes) technology on photosynthetic parameters and plant yield. Two kinds of LED lamps with different spectral properties were used. The first emitted a white light and the second a mixture of red and blue light. Measurements of chlorophyll fluorescence and gas exchange were taken in natural and artificial light. Control plants were not treated with additional lighting. During the day with natural light in March (winter growing), photosynthesis intensity, stomatal conductance and transpiration of lamb's lettuce leaves were higher than in November (autumn growing). In the evening hours of March and November, during artificial plant lighting, similar photosynthesis intensity was observed. This intensity was significantly higher than in the afternoon hours (by natural light) in the autumn. The highest content of chlorophyll a, b and carotenoids was found in the treatment with red + blue LEDs in winter growing. Supplemental lighting with red+blue LED light stimulated the high efficiency of the photosynthetic apparatus, which was manifested by the highest Performance Index (PI). The highest weight of the rosettes was noted in the autumn growing period in plants that were under the influence of the red+blue supplemental lighting followed by the white LED. This could be the result of a significant stimulation of photosynthesis during supplemental lighting with the LED lamps during this period.
\end{abstract}

Key words: chlorophyll fluorescence, gas exchange, photosynthetic pigments, SSL LED

\section{INTRODUCTION}

Studies on the application of light-emitting diodes (LEDs) in plant culture systems have been conducted for over 20 years. Following the development of the technology of solid-state lighting using
LEDs, various applications in horticulture have already been discovered (Wright 2011). As a result of the high costs of these systems, most studies were connected with small-scale horticultural applications such as in vitro cultures (Kurlicik

\footnotetext{
*Corresponding author.

Tel.: +48 126625208 ;

e-mail: r.wojciechowska@ogr.ur.krakow.pl (R. Wojciechowska).
} 
et al. 2008), or in chamber conditions (Heo et al. 2002). According to Morrow (2008), light output has increased while device costs have decreased, so LED use for large-scale horticulture might be economically feasible.

The question of whether LEDs could be a good source of light for the cultivation of plants, and for their intensive growing systems, is now a topic of horticulture studies concerning commercial production (Pinho et al. 2008, Hogewoning et al. 2010, Wright 2011). In the Netherlands, an experiment with a greenhouse-grown cucumber was recently conducted using red and blue LEDs and a canopy interlighting (Trouwborst et al. 2010). The researchers investigated leaf photosynthetic parameters, crop production and the development of plants. The obtained results are very promising. Additionally, in Poland a few studies have been conducted on the application of LEDs in supplemental radiation in greenhouse growing (Treder et al. 2012).

From the physiological point of view, light with emission peak ranges of 430, $640 \mathrm{~nm}$ (maxima absorption for chlorophyll a), 450, 660 $\mathrm{nm}$ (maxima for chlorophyll b), and 440-480 nm (for carotenoids) is the most efficient in enhancing photosynthesis (Taiz and Zeiger 2011). Owing to the unique capability of spectral composition control, LED systems are very useful in a wide range of plant physiology experiments. Blue and red light LEDs have often proven useful for plant growth (Lian et al. 2002, Kim et al. 2004). Research concerning the influence of white LED light has also been conducted (Wang et al. 2009).

According to specialists in other countries (Morrrow 2008, Pinho et al. 2008) and in Poland (Grzesiak et al. 2009), most modern SSL LED technologies can provide high light intensities simultaneously with low radiant heat and optimal spectral characteristics with regulation possibilities. These parameters enable an improvement in the photosynthetic efficiency of plants.

The aim of the presented study was the comparison of the photosynthetic parameters of lamb's lettuce as an effect of supplemental lighting with modern SSL LED technology. White and red+blue light emitted by LED lamps, specially constructed for greenhouse cultivation, were used during two growing seasons.

\section{MATERIAL AND METHODS}

The experiment was conducted in a greenhouse of the Faculty of Horticulture of the University of Agriculture in Krakow. Seeds of the lamb's lettuce (Valerianella locusta Laterr. Em Betce) 'Noordhollandse' cultivar were sown into peat substrate in 12 plastic trays with 24 cells twice, on 20 January and 5 October 2011, for winter and autumn growing, respectively. The composition of peat substrate was as follows (in $\mathrm{mg} \mathrm{dm}^{-3}$ ): $\mathrm{N}-117$, $\mathrm{P}-94, \mathrm{~K}-344, \mathrm{Ca}-1324, \mathrm{Mg}-34, \mathrm{pH}=6.5$. No additional soil mineral fertilisation was applied. Ten days after sowing, the supplemental lighting was implemented.

Two SSL LED (Solid State Lighting Light Emitting Diodes) lamps were used in the experiment. A detailed description of the system has been published in Elektronika (Grzesiak et al. 2011). Its designers used the most modern SSL LED technology in 2011 to provide extra light in the greenhouse. The spectral properties of the lamps coded with the symbols $\mathrm{R} / \mathrm{W}$ and $\mathrm{R} / \mathrm{R}+\mathrm{B}$ are presented in Figure 1. The ratio of red and blue in $\mathrm{R} / \mathrm{R}+\mathrm{B}$ LED lamp was $1: 0.8$. The measurements were taken at a distance of $40 \mathrm{~cm}$ under the lamp (on the plant level when photosynthetic parameters were measured). In both cases, photosynthetic photon flux density (PPFD) was $100 \mu \mathrm{mol} \mathrm{m} \mathrm{m}^{-2} \mathrm{~s}^{-1}$.

The plants were lighted every day from 5 p.m. till 10 p.m. until harvest which was conducted on 10 March and 6 December 2011, respectively. The lamps were placed at a height of $50 \mathrm{~cm}$, under the containers. The mean temperature in winter growing was $21^{\circ} \mathrm{C}$, and in autumn $17^{\circ} \mathrm{C}$. The relative air humidity was about $65 \%$ in both growing seasons. The control plants grew in the same greenhouse conditions but without supplemental lighting. Each of the three treatments (control and two LEDs) consisted of 120 plants.

After a 30-day period of supplemental lighting, measurements of gas exchange and chlorophyll fluorescence were taken, together with leaf samples of fully matured leaves from the middle part of the rosette in order to analyse the content of assimilatory pigments. These measurements were done on 1 March and 14 November between 1 p.m. and 2 p.m. (under natural light) and at 8 p.m. and 9 p.m. (under artificial light). During the day, measurements of gas exchange were performed with daylight intensity in the scope of PAR 180$200 \mu \mathrm{mol} \mathrm{m}^{-2} \mathrm{~s}^{-1}$ in March and 100-120 $\mu \mathrm{mol} \mathrm{m}^{-2} \mathrm{~s}^{-1}$ in November. Under the R/W lamp, which emitted white light, photosynthetic photon flux density (PPFD) during the period of measurement was 100 $\mu \mathrm{mol} \mathrm{m} \mathrm{m}^{-2} \mathrm{~s}^{-1}$, just as under the $\mathrm{R} / \mathrm{R}+\mathrm{B}$ lamp, which emitted rose-coloured light. Measurements were 


\section{PXM R/W}

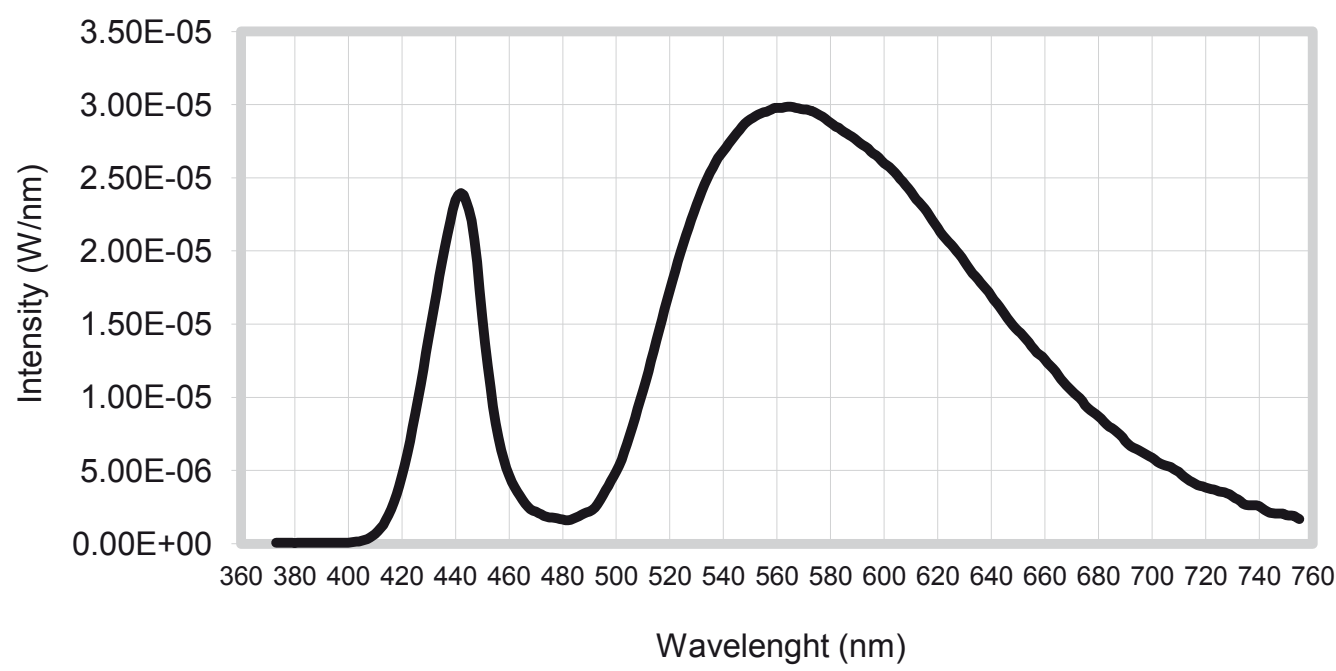

PXM R/R+B

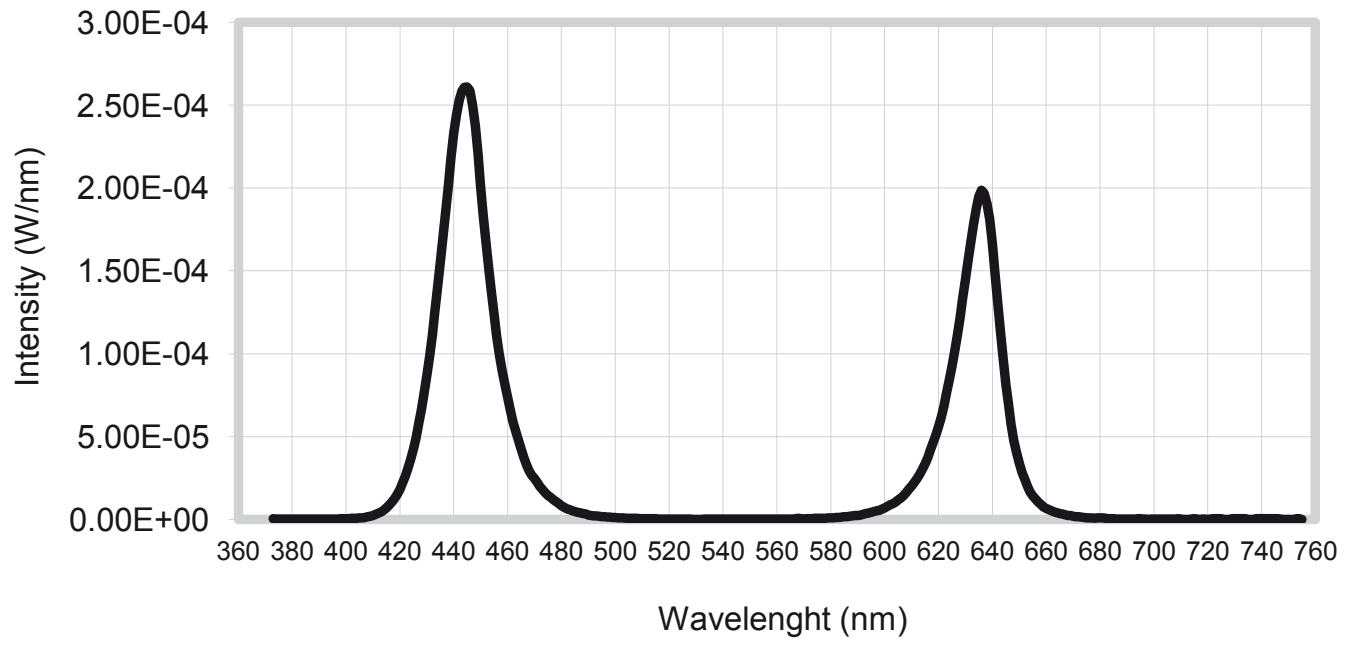

Figure 1. Spectral distribution of the LED lamps used in this study: R/W emitted white light and $R / R+B$ emitted red and blue light. This characteristic was measured at a distance of $40 \mathrm{~cm}$ under the lamp (on the plant level when photosynthesis parameters were measured)

done in the following ambient temperature and $\mathrm{CO}_{2}$ concentration conditions: 1 March: $25^{\circ} \mathrm{C}, 420$ $\mu \mathrm{mol} \mathrm{mol}{ }^{-1}$ afternoon and $16^{\circ} \mathrm{C}, 430 \mu \mathrm{mol} \mathrm{mol}^{-1}$ in the evening; 14 November: $21^{\circ} \mathrm{C}, 550 \mu \mathrm{mol} \mathrm{mol}^{-1}$ afternoon and $14^{\circ} \mathrm{C}, 590 \mu \mathrm{mol} \mathrm{mol}^{-1}$ in the evening.

Gas exchange measurement was determined using a LCi portable gas exchange system (ADC UK). The fluorescence of chlorophyll a was estimated using a Heandy Pea fluorometer (Hansatech Instruments Ltd. UK). Photosynthetic pigments were determined according to Wellbourn's spectrophotometric method (Wellburn 1994). Gas exchange and chlorophyll fluorescence were done in six replications, and pigments content in three replications. The results were subjected to an analysis of variance and means separation using the NIR Fisher test at $\mathrm{p}=0.05$.

\section{RESULTS AND DISCUSSION}

During the day in March (winter growing), photosynthesis intensity, stomatal conductance of $\mathrm{CO}_{2}$ (gs) and transpiration of lamb's lettuce leaves were higher than in November (Tab. 1). This could be a result of better light conditions and higher 
Table 1. Effect of supplemental LED lighting on gas exchange and chlorophyll fluorescence in lamb`s lettuce leaves measured by natural light

\begin{tabular}{llccccc}
\hline $\begin{array}{l}\text { Growing } \\
\text { season }\end{array}$ & $\begin{array}{l}\text { Light } \\
\text { treatment }\end{array}$ & $\begin{array}{c}\mathrm{A} \\
\mu \mathrm{mol} \mathrm{CO} \mathrm{m}^{-2} \mathrm{~s}^{-1}\end{array}$ & $\begin{array}{c}\mathrm{gs} \\
\mathrm{mol} \mathrm{CO}_{2} \mathrm{~m}^{-2} \mathrm{~s}^{-1}\end{array}$ & $\begin{array}{c}\mathrm{E} \\
\mathrm{mol} \mathrm{H}_{2} \mathrm{O} \mathrm{m}^{-2} \mathrm{~s}^{-1}\end{array}$ & $\mathrm{Fv} / \mathrm{Fm}$ & $\mathrm{PI}$ \\
\hline \multirow{4}{*}{ Winter } & Control & $8.093 \mathrm{c}^{*}$ & $0.230 \mathrm{~b}$ & $2.778 \mathrm{~b}$ & $0.833 \mathrm{a}$ & $5.201 \mathrm{a}$ \\
& $\mathrm{R} / \mathrm{W}$ & $6.932 \mathrm{~b}$ & $0.243 \mathrm{~b}$ & $4.182 \mathrm{c}$ & $0.838 \mathrm{ab}$ & $5.866 \mathrm{a}$ \\
& $\mathrm{R} / \mathrm{R}+\mathrm{B}$ & $7.487 \mathrm{bc}$ & $0.272 \mathrm{~b}$ & $3.148 \mathrm{~b}$ & $0.839 \mathrm{~b}$ & $7.622 \mathrm{~b}$ \\
\hline \multirow{4}{*}{ Autumn } & Control & $2.512 \mathrm{a}$ & $0.037 \mathrm{a}$ & $0.627 \mathrm{a}$ & $0.837 \mathrm{ab}$ & $5.955 \mathrm{a}$ \\
& $\mathrm{R} / \mathrm{W}$ & $2.915 \mathrm{a}$ & $0.053 \mathrm{a}$ & $1.187 \mathrm{a}$ & $0.848 \mathrm{c}$ & $5.859 \mathrm{a}$ \\
& $\mathrm{R} / \mathrm{R}+\mathrm{B}$ & $3.273 \mathrm{a}$ & $0.065 \mathrm{a}$ & $1.193 \mathrm{a}$ & $0.850 \mathrm{c}$ & $7.572 \mathrm{~b}$ \\
\hline
\end{tabular}

*Values marked with the same letter within columns do not differ significantly at $\mathrm{p}=0.05$

Legend: A - Photosynthetic rate, gs - stomatal conductance of $\mathrm{CO}_{2}, \mathrm{E}$ - transpiration, Fv/Fm - maximum photochemical efficiency of PSII, PI - performance index parameter, R/W - white LED lamp, $\mathrm{R} / \mathrm{R}+\mathrm{B}$ - red plus blue LED lamp

Table 2. Effect of supplemental LED lighting on gas exchange and chlorophyll fluorescence in lamb`s lettuce leaves measured by natural light (afternoon) and artificial light (evening)

\begin{tabular}{lllccccc}
\hline $\begin{array}{l}\text { Growing } \\
\text { season }\end{array}$ & $\begin{array}{l}\text { Time of the } \\
\text { day }\end{array}$ & $\begin{array}{l}\text { Light } \\
\text { treatment }\end{array}$ & $\begin{array}{c}\mathrm{A} \\
\mu \mathrm{mol} \mathrm{CO} \mathrm{m}^{-2} \mathrm{~s}^{-1}\end{array}$ & $\begin{array}{c}\mathrm{gs} \\
\mathrm{mol} \mathrm{CO}_{2} \mathrm{~m}^{-2} \mathrm{~s}^{-1}\end{array}$ & $\begin{array}{c}\mathrm{E} \\
\mathrm{mol} \mathrm{H}_{2} \mathrm{O} \mathrm{m}^{-2} \mathrm{~s}^{-1}\end{array}$ & $\mathrm{Fv} / \mathrm{Fm}$ & $\mathrm{PI}$ \\
\hline \multirow{4}{*}{ Winter } & Afternoon & $\mathrm{R} / \mathrm{W}$ & $6.932 \mathrm{~cd}$ & $0.243 \mathrm{~b}$ & $4.182 \mathrm{c}$ & $0.838 \mathrm{a}$ & $5.866 \mathrm{~b}$ \\
& Afternoon & $\mathrm{R} / \mathrm{R}+\mathrm{B}$ & $7.487 \mathrm{~d}$ & $0.272 \mathrm{~b}$ & $3.148 \mathrm{~b}$ & $0.839 \mathrm{a}$ & $7.622 \mathrm{c}$ \\
& Evening & $\mathrm{R} / \mathrm{W}$ & $5.272 \mathrm{~b}^{*}$ & $0.055 \mathrm{a}$ & $1.012 \mathrm{a}$ & $0.848 \mathrm{~cd}$ & $6.673 \mathrm{~b}$ \\
& Evening & $\mathrm{R} / \mathrm{R}+\mathrm{B}$ & $5.887 \mathrm{bc}$ & $0.075 \mathrm{a}$ & $1.162 \mathrm{a}$ & $0.841 \mathrm{ab}$ & $7.583 \mathrm{c}$ \\
\hline \multirow{4}{*}{ Autumn } & Afternoon & $\mathrm{R} / \mathrm{W}$ & $2.915 \mathrm{a}$ & $0.053 \mathrm{a}$ & $1.187 \mathrm{a}$ & $0.848 \mathrm{~cd}$ & $5.859 \mathrm{~b}$ \\
& Afternoon & $\mathrm{R} / \mathrm{R}+\mathrm{B}$ & $3.273 \mathrm{a}$ & $0.065 \mathrm{a}$ & $1.193 \mathrm{a}$ & $0.850 \mathrm{~cd}$ & $7.572 \mathrm{c}$ \\
& Evening & $\mathrm{R} / \mathrm{W}$ & $4.857 \mathrm{~b}$ & $0.052 \mathrm{a}$ & $0.637 \mathrm{a}$ & $0.850 \mathrm{~d}$ & $4.996 \mathrm{a}$ \\
& Evening & $\mathrm{R} / \mathrm{R}+\mathrm{B}$ & $5.693 \mathrm{~b}$ & $0.062 \mathrm{a}$ & $0.827 \mathrm{a}$ & $0.845 \mathrm{bc}$ & $6.269 \mathrm{~b}$ \\
\hline
\end{tabular}

*See Table 1

temperatures in the greenhouse (see Material and methods). Transpiration in November was lower because of the lower ambient temperatures during this season. However, in evening hours during plant lighting (Tab. 2), similar photosynthesis and the gs of lamb's lettuce leaves in both growing seasons were observed.

According to Wang et al. (2009), blue and purple LED light stimulated stomatal conductance in leaves of Cucumis sativus, and photosynthesis as a consequence in comparison to other studied LEDs. In the present experiment, the blue light emitted by the $\mathrm{R} / \mathrm{R}+\mathrm{B}$ lamp had no significant effect on the stomatal conductance of lamb's lettuce leaves. In this case, only a tendency was observed. In autumn evening (Tab. 2) a significant increase of photosynthesis intensity was observed in the plants that were treated with red+blue followed by white radiation in comparison with afternoon measurements (during natural light). An average increase was $70 \%$. Because of similar light intensity and $\mathrm{CO}_{2}$ concentration during afternoon and evening measurements in this growing season (see Material and methods), these results showed a very positive effect of the light emitted by LED lamps on Valerianella locusta photosynthesis. A clear stimulation of photosynthesis intensity during supplemental lighting with the red+blue light in the autumn in connection with lower temperature requirements for this species (which prevailed in that period), resulted in obtaining rosettes with the highest weight (Tab. 2, Fig. 2). In this case, the mean rosette weight was $6.12 \mathrm{~g}$. These results showed the higher effectiveness of LED lighting of lamb`s lettuce during autumn growing.

The Fv/Fm ratio is often used to indicate the maximum quantum efficiency of Photosystem II and is also defined as the maximum photochemical yield of PS II in the dark-adapted state. Healthy plant samples achieve a maximum Fv/Fm value of 0.850 (Kalaji and Guo 2008) or 0.830 according to other researchers (Hall and Rao 1999). Decreasing these values is widely considered as a PS II reaction to biotic or abiotic stress factors. The measurements taken during the day showed that this parameter achieved higher values in plants with red+blue LED lighting in comparison to the control plants, 
which show a very high capacity for photochemical quenching of energy within PS II (Tab. 1).

Interestingly, in combination with the $\mathrm{R} / \mathrm{R}+\mathrm{B}$ lamp, the PI parameter in the lamb's lettuce leaves also achieved the highest values in comparison to the other treatments, in both periods of growing (Tabs 1 and 2). On average, these values were about $33 \%$ higher in both growing cycles than in the other cases. According to Kalaji and Guo (2008), PI plays a key role in sample vitality identification. The value of this parameter is directly proportional, among others, to the concentration of active reaction centres or to the force of the light reactions. This plant reaction to red and blue supplemental lighting could have resulted in achieving a high yield of lamb's lettuce in both growing cycles in comparison to other treatments (Fig. 2).
The highest content of chlorophyll a, b and carotenoids was found in the treatment with red+blue LEDs during winter growing (Tab. 3). These and other researchers' results confirm that leaves under red plus blue LEDs contain more chlorophyll and carotenoids in comparison to other treatments (Shin et al. 2008, Hogewoning et al. 2010). In November, the control plants also showed a similar content of photosynthetic pigments to those under the red+blue lamp. However, the average weight of the lamb's lettuce rosette in control treatment was at that moment three and a half times lower as the one that was supplementary lighted with the red+blue light (Fig. 2). The smallest amount of photosynthetic pigments in the entire experiment was found in the lamb's lettuce leaves supplemented with white LEDs in the autumn growing season. Indeed, leaves of plants from this treatment were

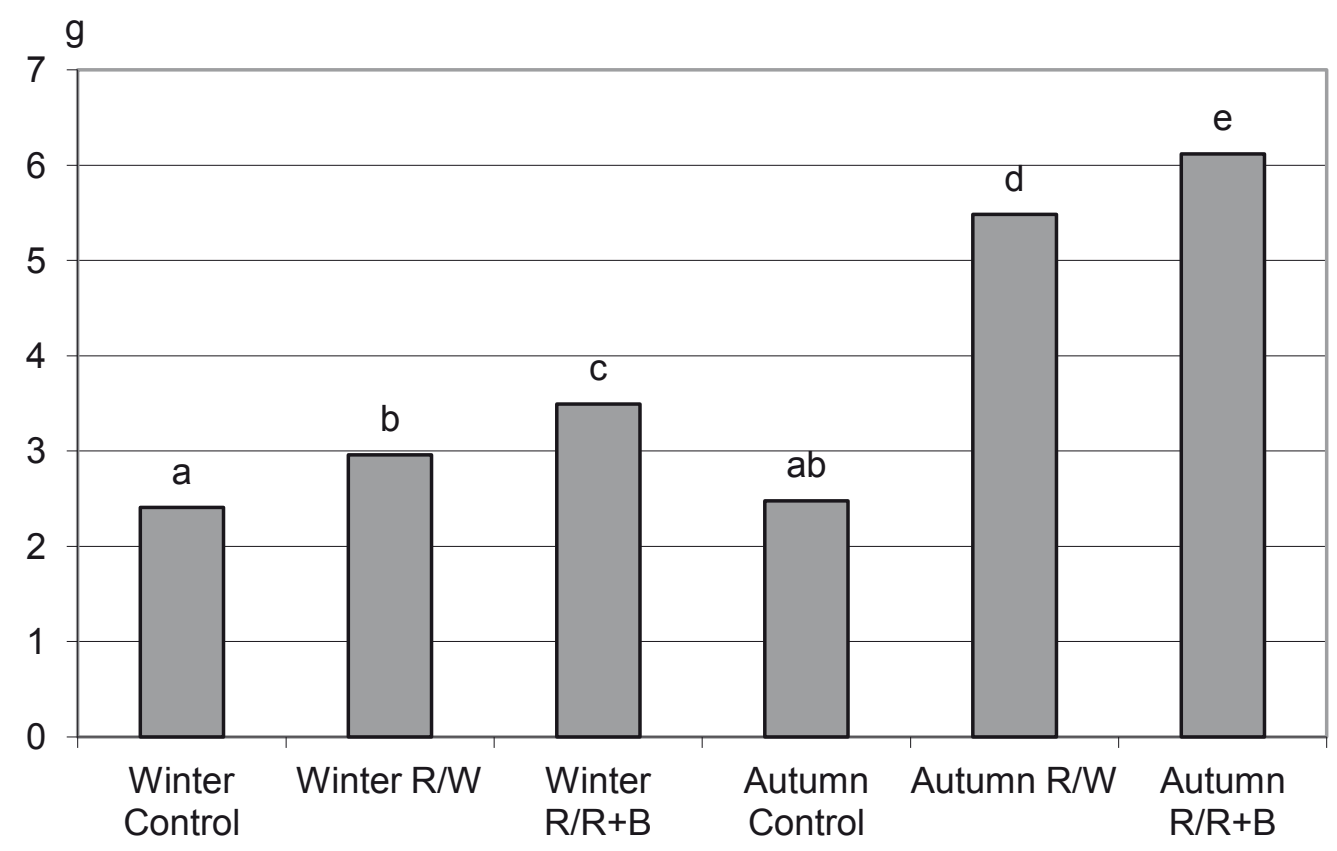

Figure 2. Mean weight of lamb's lettuce rosette $(\mathrm{g})$ in winter and autumn growing as an effect of supplemental lighting with SSL LED system (R/W - white LED lamp, R/R+B - red plus blue LED lamp)

Table 3. Photosynthetic pigment content (mg g-1 fresh weight) in lamb's lettuce as an effect of supplemental lighting with LED lamps (R/W - white LED lamp, $\mathrm{R} / \mathrm{R}+\mathrm{B}$ - red plus blue LED lamp)

\begin{tabular}{|c|c|c|c|c|c|}
\hline $\begin{array}{l}\text { Growing } \\
\text { season }\end{array}$ & $\begin{array}{l}\text { Light } \\
\text { treatment }\end{array}$ & Chlorophyll a & Chlorophyll b & Chlorophyll a + b & Carotenoids \\
\hline \multirow{3}{*}{ Winter } & Control & $1.088 c^{*}$ & $0.275 \mathrm{~b}$ & $1.363 \mathrm{c}$ & $0.260 \mathrm{c}$ \\
\hline & $\mathrm{R} / \mathrm{W}$ & $1.151 \mathrm{c}$ & $0.301 \mathrm{bc}$ & $1.453 \mathrm{c}$ & $0.268 \mathrm{~cd}$ \\
\hline & $\mathrm{R} / \mathrm{R}+\mathrm{B}$ & $1.244 \mathrm{~d}$ & $0.333 \mathrm{c}$ & $1.577 \mathrm{~d}$ & $0.282 \mathrm{~d}$ \\
\hline \multirow{3}{*}{ Autumn } & Control & $0.730 \mathrm{~b}$ & $0.200 \mathrm{a}$ & $0.929 \mathrm{~b}$ & $0.152 \mathrm{~b}$ \\
\hline & $\mathrm{R} / \mathrm{W}$ & $0.608 \mathrm{a}$ & $0.168 \mathrm{a}$ & $0.777 \mathrm{a}$ & $0.123 \mathrm{a}$ \\
\hline & $\mathrm{R} / \mathrm{R}+\mathrm{B}$ & $0.728 \mathrm{~b}$ & $0.192 \mathrm{a}$ & $0.920 \mathrm{~b}$ & $0.154 \mathrm{~b}$ \\
\hline
\end{tabular}

*Values marked with the same letter within columns do not differ significantly at $\mathrm{p}=0.05$ 
clearly lighter than in the other ones. It is a very interesting observation, taking into consideration the various preferences of consumers for green vegetables. Moreover, in this case, the mean weight of the lamb's lettuce rosette $(5.48 \mathrm{~g})$ was over twice as high as the control $(2.48 \mathrm{~g})$.

\section{CONCLUSIONS}

1. A clear stimulation of the lamb's lettuce photosynthesis intensity during supplemental lighting with LED R/R+B (red+blue) and R/W (white) lamps was observed in the evening hours of the autumn growing cycle, in comparison to photosynthesis by natural light.

2. The value of the Performance Index parameter (PI) in the lamb's lettuce leaves was the highest under the influence of the red+blue LED lamps in each growing season.

3. The highest average weight of lamb's lettuce rosettes was observed in the treatment supplemented with LED $\mathrm{R} / \mathrm{R}+\mathrm{B}$ followed by $\mathrm{R} / \mathrm{W}$ lamps in autumn, which indicates the higher effectiveness of supplementary lighting of plants during this period.

\section{ACKNOWLEDGEMENTS}

This study was supported partly by the Ministry of Science and Higher Education (DS 3500) and partly by the National Science Centre (Project No 2011/01/B/NZ9/00058).

\section{AUTHOR CONFLICT OF INTEREST STATEMENT}

Marek Żupnik is employed by PXM Ltd., which produced the LED system used in this work.

\section{REFERENCES}

Grzesiak W., Nowak S., Początek J., Skwarek A., Dubert F., Skoczowski A.M., CzyczyŁo-Mysza I., KuRpaska S., 2009. Application of LEDs in plants irradiation systems - challenge for today and for tomorrow. Elektronika 10: 73 -79.

Grzesiak W., Bieńkowski A., ŻupNik M., WojciechowsKa R., KoŁton A., Kurpaska S., 2011. Modern system based on the latest SSL LEDs for plant lighting. Elektronika 6: 137-139.

Hall D.O., Rao K.K., 1999. Photosynthesis. Cambridge University Press: 210-235.

Heo J., Lee C., Chakrabarty D., Peak K., 2002. Growth responses of mariagold and salvia bedding plants as affected by monochromic or mixture radiation provided by a Light-Emitting-Diode (LED). Plant Growth Regul. 38: 225-230.

Hogewoning S.W., Troumborst G., Maljaars H., Poorter H., van Leperen W., Harbinson J., 2010. Blue light dose-responses of leaf photosynthesis, morphology, and chemical composition of Cucumis sativus grown under different combinations of red and blue light. J. Exp. Botany 61(11): 3107-3117.

Kalaji H.M., Guo P., 2008. Chlorophyll fluorescence: a useful tool in barley plant breeding programs. In: Photochemistry Research Progress. A. Sanches and S.J. Gutierrez (eds), Nova Science Publishers Inc.: 447-471.

Kim S.J., Hahn E.J., Heo J.W., Paek K.Y., 2004. Effects of LEDs on net photosynthetic rate, growth and leaf stomata of chrysanthemum plantlets in vitro. Scientia Hort. 101: 143-151.

Kurlicik A., Dapkunienie S., Kurlicik G., Zilinskaite S., Zukauskas A., Duchovskis P., 2008. Effect of photoperiod duration on the growth of Chrysanthemum plantlets in vitro. Hort. Veg. Growing 27(2): 39-43.

Lian M.L., Murthy H.N., Paek K.Y., 2002. Effects of light emitting diodes (LEDs) on the in vitro induction and growth of bulblets of Lilium oriental hybrid 'Pesaro'. Scienta Hort. 94: 365-370.

Morrow R.C., 2008. LED lighting in Horticulture. HortScience 43(7): 1947-1950.

Pinho P., Rosvall T., Tetri E., Eloholma M., Halonen L., 2008. Light emitting diodes in plant growth: Comparative growth test in greenhouse and evaluation of photosynthetic radiation. Helsinki Univ. Technol., Department of Electronics - Lighting Unit, Espoo, Tech. Rep. 48.

Shin K.S., Murthy H.N., Heo J.W., Hahn E.J., Paek K.Y., 2008. The effect of light quality on the growth and development of in vitro cultured Doritaenopsis plants. Acta Physiol. Plant. 30: 339-343.

Treder J., Klamkowski K., Treder W., Puternicki A., LisAK E., 2012. Effect of supplemental lighting using high pressure sodium lamps and LED lamps on selected growth parameters of bedding plants. Prace Instytutu Elektrotechniki 256: 144-154.

Trouwborst G., Oosterkamp J., Hogewoning S.W., Harbinson J., van LePEREN W., 2010. The responses of light interception, photosynthesis and fruit yield of cucumber to LED-lighting within the canopy. Physiol. Plant. 138: 289-300.

TaizL.,Zeiger E., 2011. Plant Physiology.Photosynthesis: the light reactions. Sinauer Associated Inc.: 126-158.

Wang H., Gu M., Ciu J., Shi K., Zhou Y., Yu J., 2009. Effects of light on $\mathrm{CO}_{2}$ assimilation, chlorophyll quenching, expression of Calvin cycle genes and carbohydrate accumulation in Cucumis sativus. J. Photochem. Photobiol. B: Biology 96: 30-37.

Wellburn A.R., 1994. The spectral determination of chlorophylls a and b, as well as total carotenoids, 
using various solvents with spectrophotometers of different resolution. J. Plant Physiol. 144: 307-313.

Wright M., 2011. Precise LED wavelengths spur plant growth. LEDsmagazine.com, April/May 2011.

\section{WPŁYW DOŚWIETLANIA ŚWIATŁEM LED NA WYBRANE PARAMETRY FOTOSYNTEZY VALERIANELLA LOCUSTA LATERR. EM BETCE W DWÓCH TERMINACH UPRAWY}

Streszczenie: Eksperyment przeprowadzono w sezonie zimowym i jesiennym 2011 roku z użyciem roszponki jako rośliny testowej. Celem badań było określenie wpływu doświetlania uzupełniającego (przedłużającego dzień) z użyciem najnowszej technologii SSL LED (Solid State Lighting Light Emitting Diodes) na wybrane parametry fotosyntezy oraz plonowanie roślin. Zastosowano dwa rodzaje lamp LED o zróżnicowanych właściwościach spektralnych. Jedna lampa emitowała światło białe, druga czerwone i niebieskie. Pomiary fluorescencji chlorofilu i wymiany gazowej wykonywano zarówno w świetle naturalnym, jak i sztucznym. Rośliny kontrolne nie traktowano dodatkowym doświetlaniem. W czasie dnia, przy świetle naturalnym w marcu (uprawa zimowa), intensywność fotosyntezy, przewodność szparkowa i transpiracja liści roszponki były większe niż $\mathrm{w}$ listopadzie (uprawa jesienna). W godzinach wieczornych, podczas sztucznego doświetlania roślin, zarówno $\mathrm{w}$ marcu jak i listopadzie obserwowano zbliżoną intensywność fotosyntezy. Intensywność ta była istotnie większa od oznaczonej $\mathrm{w}$ godzinach południowych (przy naturalnym świetle) jesienią. Najwyższą zawartość chlorofilu a, b i karotenoidów wykazano w kombinacji ze światłem LED czerwonym i niebieskim w zimowym sezonie uprawy. Uzupełniające doświetlanie roślin światłem czerwonym i niebieskim wpłynęło także na uzyskanie najwyższej wartości wskaźnika witalności (PI) w liściach, co wskazuje na bardzo wysoką wydajność aparatu fotosyntetycznego w roślinach tego obiektu. Największą średnią masę rozety notowano $\mathrm{w}$ uprawie jesiennej w obiekcie $\mathrm{z}$ doświetlaniem światłem czerwonym i niebieskim, a następnie białym. Mogło to wynikać $\mathrm{z}$ istotnej stymulacji fotosyntezy pod wpływem doświetlania uzupełniającego lampami LED w tym sezonie.

Received September 12, 2012; accepted January 21, 2013 